\title{
Stratigraphy, palaeoenvironmental interpretation and uplift history of Barbados based on foraminiferal and other palaeontological evidence
}

\author{
R. W. JONES \\ Geological Services Team, Exploration and Production Technology Group, BP, Chertsey Road, Sunbury-on-Thames, \\ Middlesex TW16 7LN, UK \\ (Current address: Advanced Geosciences Team, BG Group PLC, 100 Thames Valley Park Drive, Reading, \\ Berkshire RG6 1PT, UK (e-mail: Bob.Jones@bg-group.com)
}

\begin{abstract}
The ages and environments of deposition of the principal mapped units of Barbados, based on foraminiferal and other palaeontological evidence, are discussed, together with the uplift history of the island. The age of the Scotland Formation is demonstrated to be Paleocene to ?early Middle Eocene; that of the Oceanic Formation late Middle Eocene to early Early Miocene; that of the Bissex Hill Formation and Conset Marl late Early to early Late Miocene; and that of the Coral Rock Formation Middle-Late Pleistocene. The environment of deposition of the Scotland Formation is interpreted to be abyssal; that of the Oceanic Formation abyssal to be lower bathyal; that of the Bissex Hill Formation and Conset Marl middle to lower bathyal; and that of the Coral Rock Formation inner neritic. Observed elevation/age relationships imply a mean uplift rate of between $120 \mathrm{~m} \mathrm{Ma}^{-1}$ and $220 \mathrm{~m} \mathrm{Ma}^{-1}$. J. Micropalaeontol. 28(1): 37-44, May 2009.
\end{abstract}

KEYWORDS: stratigraphy, palaeoenvironmental interpretation, uplift history, Barbados, Foraminifera

\section{INTRODUCTION}

The island of Barbados is situated atop the Barbados Accretionary Prism formed by the collision between the Caribbean and Atlantic plates (Speed, 1981, 1985, 1988; Speed \& Larue, 1982; Torrini et al., 1985; Torrini, 1988; Speed et al., 1991; Driscoll \& Diebold, 1999; Machel, 2004; Gill et al., 2005). The geology and petroleum geology of the island has attracted renewed interest from the oil industry recently, following the demonstration that the oils and gases from the onshore Woodbourne Field could be typed back to the prolific 'Middle' Cretaceous La Luna-Querecual-Naparima Hill Formation petroleum system of northern South America, and that potential reservoir facies extended offshore (Dolan et al., 2004; Hill \& Schenk, 2004).

The most important mapped lithostratigraphical units on the island are, in ascending stratigraphical order: the Scotland Formation or Group or approximately equivalent 'Accretionary Basal Complex' and 'Prism Cover' (predominantly sandstone and non-calcareous mudstone); the Oceanic Formation or Group (calcareous mudstone and marl, with some volcanic ash bands); the Bissex Hill Formation and Conset Marl (calcareous mudstone and marl, unknown thickness); and the Coral Rock Formation (limestone) (Saunders, 1968; Machel, 2004; Gill et al., 2005; Fig. 1). The Coral Rock forms a protective carapace over most of the island, with the exception of the Scotland District of the Atlantic coast, where it has been eroded, and where the Scotland, Oceanic, Bissex Hill and Conset Marl have become exposed. A further unit, the Joes River Formation (mudstone), is also present, although only in a melange, such that its stratigraphical relationship to the other units is unclear.

The palaeontological content of these lithostratigraphical units has been described in a number of previous studies (Jukes-Browne \& Harrison, 1891, 1892; De Cizancourt, 1948; Beckmann, 1953; Saunders \& Cordey, 1968; Caudri, 1972; Maurrasse, 1983; Kugler et al., 1984; Saunders et al., 1984;

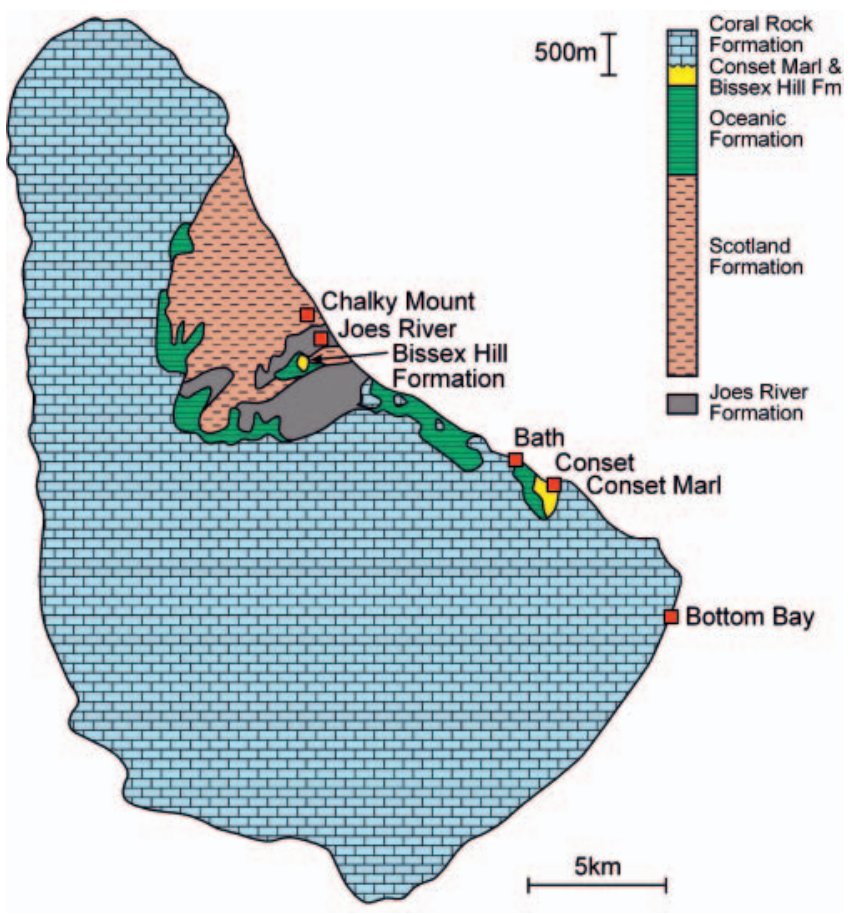

Fig. 1. Geological Map of Barbados. Note that the contact between the Oceanic Formation and the Scotland Formation is thrusted tectonic rather than stratigraphical. Note also that the Oceanic is locally overlain by the Coral Rock, with the Bissex Hill and Conset Marl unrepresented.

Steineck et al., 1984; Biju-Duval et al., 1985; Steineck \& Murtha, 1985; Wood et al., 1985; Gortner \& Larue, 1986; Bolli et al., 1994; Harding, 1996; Gill et al., 2005).

The purpose of the present study is to discuss the palaeontological, in particular the foraminiferal, evidence for the age and environment of deposition of the lithostratigraphical units, and the uplift history of the island. 


\section{DISCUSSION}

\section{Stratigraphy and palaeoenvironmental interpretation}

Palaeoenvironmental interpretation. In the case of the Scotland Formation, which contains only extinct species, palaeoenvironmental interpretation is based, in part, on the ecological ranges of those species as established by backstripping (van Morkhoven et al., 1986; Kaminski \& Gradstein, 2005) and, in part, on analogy between contained extinct and counterpart extant species, on the functional morphology of the contained extinct species, and on associated sedimentary facies (Jones, 2006). In the case of the Oceanic Formation, Bissex Hill Formation and Conset Marl, and Coral Rock Formation, which contain some still extant species, it is based in part on the ecological ranges of those species as established by empirical observation (van Morkhoven et al., 1986; Charnock \& Jones, 1990; Jones, 1994, 1998, 1999, 2006; Kaminski \& Gradstein, 2005; Tables 1-3).

\section{Scotland Formation and approximately equivalent 'Accretionary Basal Complex' and 'Prism Cover'}

Stratigraphy. To summarize, the demonstrable overall age of the Scotland Formation is interpreted as Paleocene-?early Middle Eocene, 65.5-?43 Ma, on the Gradstein et al. (2005) timescale. The minimum age is poorly constrained and is not necessarily coincident with the maximum age of the overlying Oceanic Formation (see below), as the contact between the two formations has been interpreted as thrusted tectonic rather than stratigraphical (Speed, 1988; Speed et al., 1991; J. Frampton, pers. comm., 2009).

The Scotland Formation contains no planktonic foraminifera or calcareous nannoplankton, and is not directly datable with reference to the global standard calcareous planktonic zonation schemes of the Cenozoic.

However, the Lower Scotland Formation does contain an autochthonous fauna of deep-water arenaceous or agglutinating benthonic foraminifera (Kugler et al., 1984; J. Frampton, pers. comm., 2005). It can be indirectly dated as Paleocene-Early Eocene on the basis of correlation - by means of selected agglutinating benthonic foraminiferal species - with the Lizard Springs Formation of Trinidad, which has been independently dated on planktonic foraminiferal evidence as Paleocene-Early Eocene, P1-P9=P1-E6, approximately 65.5-48.6 Ma.

The Lower and Upper Scotland Formation also contain an allochthonous fauna of shallow-water calcareous larger benthonic foraminifera (De Cizancourt, 1948; Caudri, 1972) that can be interpreted as contemporaneously transported downslope from the shelf. If this is so, the Walkers Member of the Lower Scotland Formation can be dated as Paleocene on the basis of the presence, and the Morgan Lewis Member as Early Eocene on the absence, of Actinosiphon barbadiensis, which appears to be restricted to the Paleocene. The Murphy's, Chalky Mount and Mount All members of the Upper Scotland Formation can all be dated as early Middle Eocene on the basis of the occurrence of Asterocyclina barbadiensis, Eoconuloides senni and Neodiscocyclina anconensis, which appear to be restricted to the early Middle Eocene, 48.6-43 Ma.

Note, though, that the allochthonous fauna of shallow-water calcareous larger benthonic foraminifera can also be interpreted

\begin{tabular}{|c|c|c|c|c|c|c|c|}
\hline Species & IN & $\mathrm{MN}$ & $\mathrm{ON}$ & UB & MB & LB & $\mathrm{AB}$ \\
\hline Siphogenerina raphanus & $\mathrm{X}$ & $\mathrm{X}$ & $\mathrm{X}$ & $\mathrm{X}$ & & & \\
\hline Fissurina laevigata & $\mathrm{X}$ & $\mathrm{X}$ & $\mathrm{X}$ & $\mathrm{X}$ & $\mathrm{X}$ & $X$ & $\mathrm{X}$ \\
\hline Fissurina lagenoides & $\mathrm{X}$ & $\mathrm{X}$ & $\mathrm{X}$ & $\mathrm{X}$ & $\mathrm{X}$ & $\mathrm{X}$ & $\mathrm{X}$ \\
\hline Globocassidulina subglobosa & $\mathrm{X}$ & $\mathrm{X}$ & $\mathrm{X}$ & $\mathrm{X}$ & $\mathrm{X}$ & $\mathrm{X}$ & $\mathrm{X}$ \\
\hline Anomalinoides bilateralis & & $\mathrm{X}$ & & & & & \\
\hline Cibicidoides pachyderma & & $\mathrm{X}$ & $\mathrm{X}$ & $\mathrm{X}$ & $\mathrm{X}$ & $\mathrm{X}$ & $\mathrm{X}$ \\
\hline Sphaeroidina bulloides & & $\mathrm{X}$ & $\mathrm{X}$ & $\mathrm{X}$ & $\mathrm{X}$ & $\mathrm{X}$ & $\mathrm{X}$ \\
\hline Lenticulina torrida & & & $\mathrm{X}$ & $\mathrm{X}$ & $\mathrm{X}$ & & \\
\hline Plectofrondicularia vaughani & & & $\mathrm{X}$ & $\mathrm{X}$ & $\mathrm{X}$ & & \\
\hline Cibicidoides eocaenus & & & $\mathrm{X}$ & $\mathrm{X}$ & $\mathrm{X}$ & $\mathrm{X}$ & \\
\hline Gavelinella micra & & & $\mathrm{X}$ & $\mathrm{X}$ & $\mathrm{X}$ & $\mathrm{X}$ & $\mathrm{X}$ \\
\hline Psammosphaera fusca & & & $\mathrm{X}$ & $\mathrm{X}$ & $\mathrm{X}$ & $\mathrm{X}$ & $\mathrm{X}$ \\
\hline Pullenia quinqueloba & & & $\mathrm{X}$ & $\mathrm{X}$ & $\mathrm{X}$ & $\mathrm{X}$ & $\mathrm{X}$ \\
\hline Saccammina grzybowskii & & & $\mathrm{X}$ & $\mathrm{X}$ & $\mathrm{X}$ & $\mathrm{X}$ & $\mathrm{X}$ \\
\hline Usbekistania charoides & & & $\mathrm{X}$ & $\mathrm{X}$ & $\mathrm{X}$ & $\mathrm{X}$ & \\
\hline Bulimina alazanensis & & & & $\mathrm{X}$ & & & \\
\hline Pleurostomella brevis & & & & $\mathrm{X}$ & & & \\
\hline Recurvoides turbinatus & & & & $\mathrm{X}$ & & & \\
\hline Orthomorphina consobrina & & & & $\mathrm{X}$ & $\mathrm{X}$ & & \\
\hline Ammodiscus glabratus & & & & $\mathrm{X}$ & $\mathrm{X}$ & $\mathrm{X}$ & \\
\hline Buliminella grata & & & & $\mathrm{X}$ & $\mathrm{X}$ & $\mathrm{X}$ & \\
\hline Hormosina trinitatensis & & & & $\mathrm{X}$ & $\mathrm{X}$ & $\mathrm{X}$ & \\
\hline Hyperammina friabilis & & & & $\mathrm{X}$ & $\mathrm{X}$ & $\mathrm{X}$ & \\
\hline Trochammina altiformis & & & & $\mathrm{X}$ & $\mathrm{X}$ & $\mathrm{X}$ & \\
\hline Alabaminoides exiguus & & & & $\mathrm{X}$ & $\mathrm{X}$ & $\mathrm{X}$ & $\mathrm{X}$ \\
\hline Cyclammina cancellata & & & & $\mathrm{X}$ & $\mathrm{X}$ & $\mathrm{X}$ & $\mathrm{X}$ \\
\hline Eggerella bradyi & & & & $\mathrm{X}$ & $\mathrm{X}$ & $\mathrm{X}$ & $\mathrm{X}$ \\
\hline Hyperammina elongata & & & & $\mathrm{X}$ & $\mathrm{X}$ & $\mathrm{X}$ & $\mathrm{X}$ \\
\hline Karreriella bradyi & & & & $\mathrm{X}$ & $\mathrm{X}$ & $\mathrm{X}$ & $\mathrm{X}$ \\
\hline Laticarinina pauperata & & & & $\mathrm{X}$ & $\mathrm{X}$ & $\mathrm{X}$ & $\mathrm{X}$ \\
\hline Lituotuba lituiformis & & & & $\mathrm{X}$ & $\mathrm{X}$ & $\mathrm{X}$ & $\mathrm{X}$ \\
\hline Oridorsalis umbonatus & & & & $\mathrm{X}$ & $\mathrm{X}$ & $\mathrm{X}$ & $\mathrm{X}$ \\
\hline Planulina renzi & & & & $\mathrm{X}$ & $\mathrm{X}$ & $\mathrm{X}$ & $\mathrm{X}$ \\
\hline Pullenia bulloides & & & & $\mathrm{X}$ & $\mathrm{X}$ & $\mathrm{X}$ & $\mathrm{X}$ \\
\hline Spiroplectammina trinitatensis & & & & $\mathrm{X}$ & $\mathrm{X}$ & $\mathrm{X}$ & $\mathrm{X}$ \\
\hline Stilostomella consobrina & & & & $\mathrm{X}$ & $\mathrm{X}$ & $\mathrm{X}$ & $\mathrm{X}$ \\
\hline Trochamminoides proteus & & & & $\mathrm{X}$ & $\mathrm{X}$ & $\mathrm{X}$ & $\mathrm{X}$ \\
\hline Veleroninoides scitulus & & & & $\mathrm{X}$ & $\mathrm{X}$ & $\mathrm{X}$ & $\mathrm{X}$ \\
\hline Bulimina impendens & & & & & $\mathrm{X}$ & & \\
\hline Bulimina trinitatensis & & & & & $\mathrm{X}$ & & \\
\hline Hanzawaia ammophila & & & & & $\mathrm{X}$ & & \\
\hline Osangularia mexicana & & & & & $\mathrm{X}$ & & \\
\hline Cibicidoides mexicanus & & & & & $\mathrm{X}$ & $\mathrm{X}$ & \\
\hline Uvigerina rippensis & & & & & $\mathrm{X}$ & $\mathrm{X}$ & \\
\hline Anomalinoides semicribratus & & & & & $\mathrm{X}$ & $\mathrm{X}$ & $\mathrm{X}$ \\
\hline Cibicidoides laurisae & & & & & $\mathrm{X}$ & $\mathrm{X}$ & $\mathrm{X}$ \\
\hline Cibicidoides havanensis & & & & & $\mathrm{X}$ & $\mathrm{X}$ & $\mathrm{X}$ \\
\hline Duquepsammia cubensis & & & & & $\mathrm{X}$ & $\mathrm{X}$ & $\mathrm{X}$ \\
\hline Gavelinella semicribrata & & & & & $\mathrm{X}$ & $\mathrm{X}$ & $\mathrm{X}$ \\
\hline Plectofrondicularia paucicostata & & & & & $\mathrm{X}$ & $\mathrm{X}$ & $\mathrm{X}$ \\
\hline Cibicidoides haitiensis & & & & & & $\mathrm{X}$ & \\
\hline Quadrimorphina profunda & & & & & & $\mathrm{X}$ & \\
\hline Äbyssamina spp. & & & & & & $\mathrm{X}$ & $\mathrm{X}$ \\
\hline Alabamina dissonata & & & & & & $\mathrm{X}$ & \\
\hline Bulimina jarvisi & & & & & & $\mathrm{X}$ & $\mathrm{X}$ \\
\hline Cibicidoides grimsdalei & & & & & & $\mathrm{X}$ & \\
\hline Cibicidoides havanensis & & & & & & $\mathrm{X}$ & $\mathrm{X}$ \\
\hline Marginulina obesa & & & & & & $\mathrm{X}$ & $\mathrm{X}$ \\
\hline Nuttallides truempyi & & & & & & $\mathrm{X}$ & $\mathrm{X}$ \\
\hline Fissurina alveolata & & & & & & & \\
\hline Osangulariella umbonifera & & & & & & & \\
\hline Pyrulina extensa & & & & & & & $\mathrm{X}$ \\
\hline Siphonodosaria abyssorum & & & & & & & \\
\hline Spirosigmoilina tenuis & & & & & & & \\
\hline
\end{tabular}

Compiled from various sources (see text). Palaeobathymetric zonation after Charnock \& Jones (1990) and Jones (1999). IN, inner neritic (0$50 \mathrm{~m}) ; \mathrm{MN}$, middle neritic $(50-100 \mathrm{~m})$; ON, outer neritic $(100-200 \mathrm{~m})$; $\mathrm{UB}$, upper bathyal $(200-1000 \mathrm{~m})$; MB, middle bathyal $(1000-1750 \mathrm{~m})$; LB, lower bathyal (1650-2250 m); AB, abyssal (>2250 m). The occurrences are consistent with a lower bathyal to abyssal environment of deposition (highlighted).

Table 1. Bathymetric ranges of benthonic foraminifera from the Oceanic Formation. 


\begin{tabular}{llllllll}
\hline Species & IN & MN & ON & UB & MB & LB & AB \\
\hline Planulina ariminensis & & $\mathrm{X}$ & $\mathrm{X}$ & $\mathrm{X}$ & $\mathrm{X}$ & $\mathrm{X}$ & $\mathrm{X}$ \\
Rectuvigerina transversa & & & & $\mathrm{X}$ & & & \\
Planulina mexicana & & & & $\mathrm{X}$ & $\mathrm{X}$ & & \\
Karreriella bradyi & & & & $\mathrm{X}$ & $\mathrm{X}$ & $\mathrm{X}$ & $\mathrm{X}$ \\
Oridorsalis umbonatus & & & & $\mathrm{X}$ & $\mathrm{X}$ & $\mathrm{X}$ & $\mathrm{X}$ \\
Osangularis mexicana & & & & & $\mathrm{X}$ & & \\
\hline
\end{tabular}

Compiled from various sources (see text). Palaeobathymetric zonation after Charnock \& Jones (1990) and Jones (1999). IN, inner neritic (0$50 \mathrm{~m})$; MN, middle neritic (50-100 m); ON, outer neritic (100-200 m); $\mathrm{UB}$, upper bathyal (200-1000 m); MB, middle bathyal (1000-1750 m); LB, lower bathyal (1650-2250 m); AB, abyssal (>2250 m). The occurrences are consistent with a middle bathyal environment of deposition (highlighted).

Table 2. Bathymetric ranges of benthonic foraminifera from the Bissex Hill Formation.

\begin{tabular}{llllllll}
\hline Species & $\mathrm{IN}$ & $\mathrm{MN}$ & $\mathrm{ON}$ & $\mathrm{UB}$ & $\mathrm{MB}$ & $\mathrm{LB}$ & $\mathrm{AB}$ \\
\hline Globocassidulina subglobosa & $\mathrm{X}$ & $\mathrm{X}$ & $\mathrm{X}$ & $\mathrm{X}$ & $\mathrm{X}$ & $\mathrm{X}$ & $\mathrm{X}$ \\
Sphaeroidina bulloides & & $\mathrm{X}$ & $\mathrm{X}$ & $\mathrm{X}$ & $\mathrm{X}$ & $\mathrm{X}$ & \\
Cibicidoides pachyderma & & $\mathrm{X}$ & $\mathrm{X}$ & $\mathrm{X}$ & $\mathrm{X}$ & $\mathrm{X}$ & $\mathrm{X}$ \\
Sigmoilopsis schlumbergeri & & $\mathrm{X}$ & $\mathrm{X}$ & $\mathrm{X}$ & $\mathrm{X}$ & $\mathrm{X}$ & $\mathrm{X}$ \\
Plectofrondicularia vaughani & & & $\mathrm{X}$ & $\mathrm{X}$ & $\mathrm{X}$ & & \\
Melonis pompilioides & & & $\mathrm{X})$ & $\mathrm{X})$ & $\mathrm{X})$ & $\mathrm{X}$ & $\mathrm{X}$ \\
Rectuvigerina nodifera & & & & $\mathrm{X}$ & & & \\
Rectuvigerina transversa & & & & $\mathrm{X}$ & & & \\
Uvigerina hispida & & & & $\mathrm{X}$ & $\mathrm{X}$ & $\mathrm{X}$ & \\
Laticarinina pauperata & & & & $\mathrm{X}$ & $\mathrm{X}$ & $\mathrm{X}$ & $\mathrm{X}$ \\
Oridorsalis umbonatus & & & & $\mathrm{X}$ & $\mathrm{X}$ & $\mathrm{X}$ & $\mathrm{X}$ \\
Pullenia bulloides & & & & $\mathrm{X}$ & $\mathrm{X}$ & $\mathrm{X}$ & $\mathrm{X}$ \\
Bulimina rostrata & & & & & $\mathrm{X}$ & $\mathrm{X}$ & $\mathrm{X}$ \\
Cibicidoides wuellerstorff & & & & & & $\mathrm{X}$ & $\mathrm{X}$ \\
\hline
\end{tabular}

Compiled from various sources (see text). Palaeobathymetric zonation after Charnock \& Jones (1990) and Jones (1999). IN, inner neritic (0$50 \mathrm{~m})$; MN, middle neritic $(50-100 \mathrm{~m})$; ON, outer neritic $(100-200 \mathrm{~m})$; $\mathrm{UB}$, upper bathyal (200-1000 m); MB, middle bathyal (1000-1750 m); LB, lower bathyal (1650-2250 m); AB, abyssal (>2250 m). The occurrences are consistent with a lower bathyal environment of deposition (highlighted).

Table 3. Bathymetric ranges of benthonic foraminifera from the Conset Marl.

as non-contemporaneously reworked into rocks as young as Late Eocene, as has been demonstrated to be the case in an analogous situation in Trinidad (Caudri, 1996; J. Frampton, pers. comm., 2009), or even younger.

Note also that the so-called 'Prism Cover' overlying the 'Accretionary Basal Complex' in Woodbourne Field in Barbados, and underlying the Oceanic Formation, has been interpreted as being as young as Miocene in age (Speed et al., 1991; J. Frampton, pers. comm., 2009).

Thus, the top of the Scotland Formation can be interpreted as younger than the base of the Oceanic Formation (see below), supporting the interpretation that the contact between the two formations is thrusted tectonic rather than stratigraphical.

Palaeoenvironmental interpretation. The overall environment of the Scotland Formation is interpreted as abyssal, with water depths in the range $>2250 \mathrm{~m}(? \pm 4800 \mathrm{~m})$.
As noted above, the Scotland Formation contains an autochthonous fauna of deep-water agglutinating benthonic foraminifera (Kugler et al., 1984; Biju-Duval et al., 1985; J. Frampton, pers. comm., 2005), and an allochthonous fauna of shallowwater calcareous larger benthonic foraminifera (De Cizancourt, 1948; Caudri, 1972). The autochthonous 'deep-water agglutinating foraminifera' (DWAF) fauna, also described as a 'Rhabdammina' fauna or 'flysch-type' fauna, is indicative of a deep-marine, bathyal to abyssal, submarine fan environment of deposition (Jones, 1996, 1998, 2006). The development of DWAF faunas, and the effective absence of a calcareous component, has been interpreted as indicative of deposition below the calcite compensation depth (CCD), estimated to have been at approximately $4800 \mathrm{~m}$ in the Eocene (Saunders et al., 1984). Note, though, that the development of such faunas appears to be controlled by factors other than depth, and may be related to depth only indirectly. These factors include calcium carbonate dissolution, which favours the sustenance and/or preservation of agglutinating foraminifera over their calcareous counterparts, and which can take place above the CCD in submarine fan environments, when acids are liberated by the oxidation of organic material during diagenesis. Note also that the local occurrence of calcareous benthonic foraminifera is indicative of at least local deposition above the CCD. The calcareous benthonic foraminifera are characterized by robust form, large size and small surface area with respect to volume, rendering them resistant both to destruction during transportation and to dissolution.

The dominance of the epifaunal suspension-feeding 'morphotype' Bathysiphon ('morphogroup' A of Jones \& Charnock, 1985), and the subordination of epifaunal detritus-feeding 'morphotypes' Glomospira and Trochammina ('morphogroup' B) and infaunal detritus-feeding 'morphotypes' Bolivinopsis and Hormosina ('morphogroup' C) within the DWAF fauna is strongly suggestive of a dominance of 'turbiditic' over 'hemipelagic' deposition (Jones, 1999, 2006; Jones et al., 2005).

The Scotland Formation is also characterized by trace fossils, lithologies, sandbody morphologies and sedimentary structures consistent with an abyssal, submarine fan environment (Pudsey \& Reading, 1982; Larue \& Speed, 1983; Larue, 1985; Pudsey, 1985; Gortner \& Larue, 1986; Kasper \& Larue, 1986; Chaderton \& Wood, 2007). The trace fossils include Palaeodictyon (Pudsey \& Reading, 1982), consistent with an abyssal environment (Jones, 2006). Interestingly, they also include Ophiomorpha (pers. obs.), which is the burrowing trace of a callianassid crustacean characteristic of shallow marine, shoreface environments (Jones et al., 1999), and here evidently transported downslope. The lithologies include a predominance of medium- to coarse-grained sandstones, and the sandbody morphologies include channels, levees and lobes (Chaderton \& Wood, 2007). The sedimentary structures include unidirectional current ripples, and graded and inverse-graded bedding. The inverse-graded bedding is interpreted as having formed by 'dynamic sieving' in a 'turbidite' flow (R. Dixon, pers. comm., 2005).

Incidentally, geochemical and heavy mineral evidence indicates that the sediments of the Scotland Formation and, by inference, those of the equivalent lithostratigraphical unit drilled at ODP Site 672 on the Tiburon Rise (Beck et al., 1990; Dolan et al., 1990), were derived from a provenance area on the 
northwestern Venezuelan Shield (Mahabir et al., 2004). Whether they were derived by way of the palaeo-Orinoco or another river system remains unclear. Note in this context, though, that there is an abundance of palaeobiogeographical and other evidence to indicate that the palaeo-Orinoco discharged into the Caribbean until the Miocene, when the uplift of the Merida Andes diverted its course towards the Atlantic (Jones, 2006). In the Eocene, the palaeo-Orinoco discharged into the area around Lake Maracaibo in western Venezuela, depositing the deltaic sediments of the Misoa Formation and the incised valley fills of the Mirador Formation, potentially the up-tract equivalents of the submarine fan sediments of the Scotland Formation.

\section{Oceanic Formation}

Stratigraphy. The Oceanic Formation contains planktonic foraminifera indicative of late Middle Eocene?-?early Early Miocene Zones P12?-?N7=E10?-?M4 (Saunders et al., 1984; Biju-Duval et al., 1985; Wood et al., 1985; Bolli et al., 1994), approximately 43-17 Ma (Gradstein et al., 2005).

Palaeoenvironmental interpretation. The overall environment of the Oceanic Formation is interpreted as lower bathyal to abyssal, with water depths in the range $1650->2250 \mathrm{~m}(<4800 \mathrm{~m})$. This interpretation is consistent with those of previous authors, with water depths in the range $500-1000 \mathrm{fm}$ or approximately 900 $1800 \mathrm{~m}$ according to Jukes-Browne \& Harrison (1892), or 2000$>2800 \mathrm{~m}$ according to Saunders et al. (1984) and Wood et al. (1985).

The Oceanic Formation contains the benthonic foraminifera listed in Table 1 (Beckmann, 1953; Saunders \& Cordey, 1968; Saunders et al., 1984; Wood et al., 1985; Bolli et al., 1994). The occurrences of virtually all of the species encountered are consistent with a lower bathyal to abyssal environment of deposition, with water depths in the range $1650->2250 \mathrm{~m}$. The only exceptions are the occurrences of some shallower-water species, which are attributed to downslope transportation. Significantly, most of these species have elongate morphologies that render them hydrodynamically unstable and, therefore, susceptible to entrainment in, and downslope transportation by, 'turbidite' flows. The occurrence of calcareous benthonic foraminifera is indicative of deposition above the CCD, estimated to have been at approximately $4800 \mathrm{~m}$ in the Eocene (Saunders et al., 1984). Note, though, that there is evidence of dissolution below the lysocline of up to $90 \%$ of calcareous foraminifera in the lower part of the Oceanic Formation, although only $50 \%$ in the upper part (Saunders et al., 1984). The trend toward decreased dissolution through time is indicative of either a deepening of the lysocline, or uplift and shallowing of relative sea-level (from abyssal to lower bathyal).

It also contains planktonic foraminifera, calcareous nannoplankton, radiolarians and silicoflagellates, and 'deep-sea' benthonic ostracods. The abundance of calcareous and siliceous plankton is suggestive of a dominance of (hemi)pelagic deposition. Note, though, that the evidently comparatively high sedimentation rate is suggestive of at least some 'turbiditic' influence, or else of enhanced pelagic productivity (Saunders et al., 1984).
In addition, the Oceanic Formation also contains the trace fossil Zoophycos (pers. obs.), consistent with a bathyal environment (Jones, 2006).

\section{Bissex Hill Formation and Conset Marl}

Stratigraphy. The Bissex Hill Formation contains planktonic foraminifera indicative of late Early-early Middle Miocene Zone N8=M5 (Steineck \& Murtha, 1985; Bolli et al., 1994), approximately 17-15 Ma (Gradstein et al., 2005).

The Conset Marl contains planktonic foraminifera indicative of late Middle-?early Late Miocene Zones N9-?N15 = M6-?M12 (Steineck \& Murtha, 1985; Bolli et al., 1994), approximately 15-10Ma (Gradstein et al., 2005).

Palaeoenvironmental interpretation. The Bissex Hill Formation and Conset Marl contain the benthonic foraminifera listed in Tables 2 and 3, respectively (Steineck \& Murtha, 1985). The occurrences of virtually all of these species are consistent with a middle bathyal environment of deposition, with water depths in the range 1000-1650 m, for the Bissex Hill Formation; and a lower bathyal environment, with water depths in the range 1650-2250 m, for the Conset Marl. The only exceptions are those of some shallower-water species, which are attributed to downslope transportation.

These interpretations are deeper than those of previous authors, with water depths in the range 300-500 $\mathrm{m}$ for the Bissex Hill Formation, and 1000-1500 m for the Conset Marl (Steineck \& Murtha, 1985). The interpretations of previous authors did not take into account the possibility that the observed occurrences of shallower-water species could be attributable to downslope transportation.

\section{Coral Rock Formation}

Stratigraphy. Detailed mapping has revealed the presence of a series of up to thirteen terraces within the Coral Rock Formation that record periodic uplift from the locus of deposition effectively at or immediately below sea-level (Mesolella, 1967; Shackleton \& Matthews, 1977; Fairbanks \& Matthews, 1978; Humphrey \& Kimbell, 1990; Schellmann \& Radtke, 2004). The highest and oldest terraces (T12-T13), at heights of 110-120 m above sea-level, have been dated on electron spin resonance (ESR) evidence to Middle Pleistocene, 410 000-400000 years $\mathrm{BP}$, coincident with Marine/Oxygen Isotope Stage (M/OIS) 11 (Schellmann \& Radtke, 2004). The intermediate terraces, at heights of 45-90 m above sea-level, have been dated on ESR evidence to Middle Pleistocene, $3325000-200000$ years BP, M/OISs9-7 (antepenultimate to penultimate interglacials). The youngest and lowest terraces (T1-T5), elevated to $<5-40 \mathrm{~m}$ above sea-level, have been dated on ESR and other evidence to Late Pleistocene, 1325 000-725000 years BP, M/OIS5e (last interglacial). The observed elevation/age relationships imply a mean uplift rate, uncorrected for eustatic effects, is approximately $220 \mathrm{~m} \mathrm{Ma}^{-1}$.

Palaeoenvironmental interpretation. Analogy with the modern reef fringing the Caribbean coast of Barbados indicates that the ancient reef terraces of the Coral Rock Formation formed 


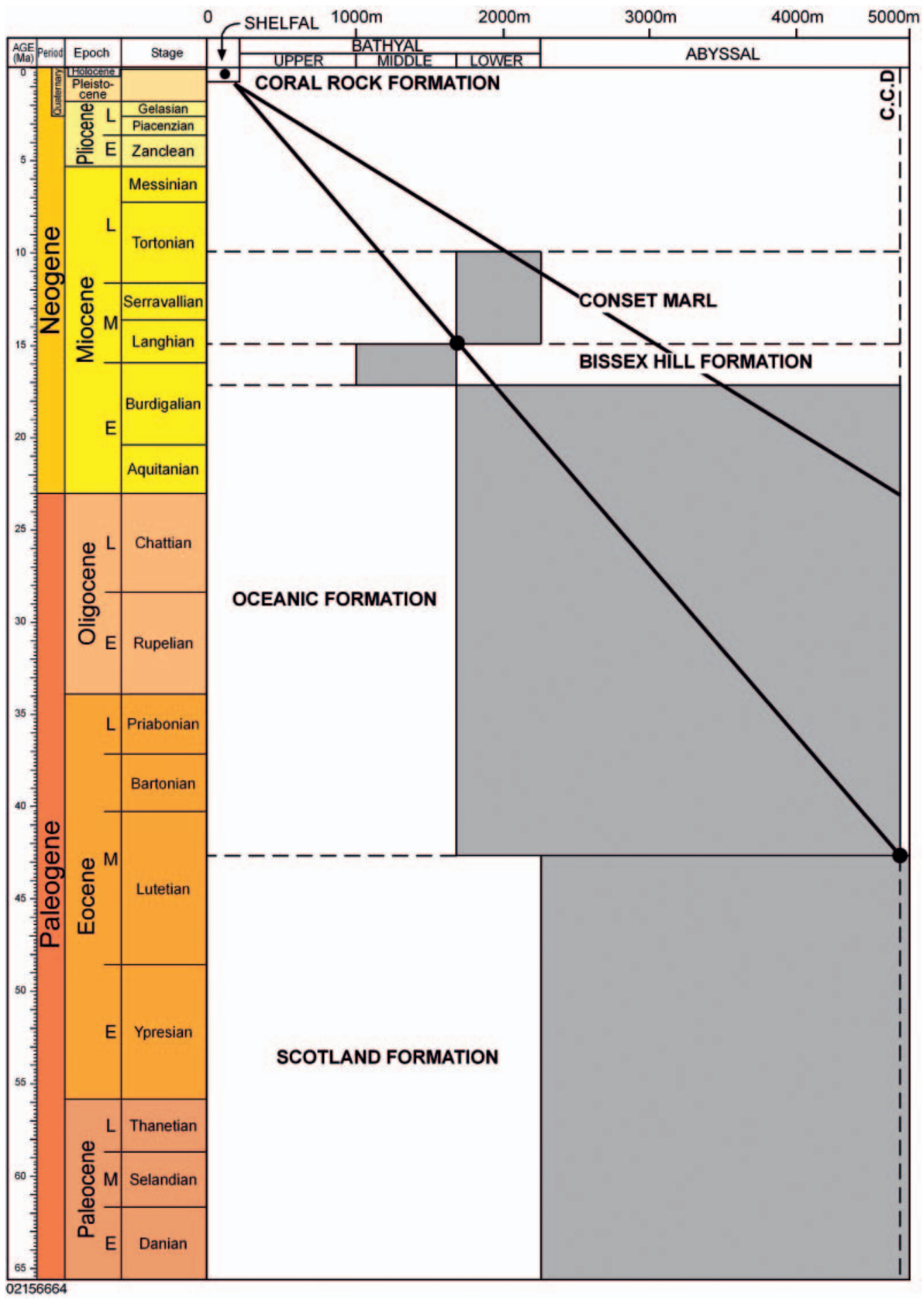

Fig. 2. Uplift history of Barbados.

effectively at or immediately below sea-level (Schellmann \& Radtke, 2004, and additional references cited therein). The reef-top, effectively at sea-level, is and was characterized by the 'Elk's Horn Coral' Acropora palmata; the reef-front, immediately $(<5 \mathrm{~m})$ below, and still well within the euphotic zone, by the 'Stag's Horn Coral' A. cervicornis. (The back-reef is and was characterized by the 'Organ-Pipe Coral' Montastrea annularis,
Porites and Siderastrea; the fore-reef by the 'Brain Coral' Diploria, Montastrea annularis, M. cavernosa and Siderastrea).

\section{Joes River Formation}

Stratigraphy. As noted above, the Joes River Formation is only present in a melange, such that its stratigraphical relationship to 
the other units is unclear. It has been interpreted as having formed by diapiric extrusion onto the seafloor (Kugler et al., 1984; Gill et al., 2005).

Palaeoenvironmental interpretation. The Joes River Formation contains a fauna of benthonic foraminifera and macrofossils (Kugler et al., 1984; Gill et al., 2005).

The benthonic foraminiferal assemblage is similar to that of the Lower Scotland Formation (Kugler et al., 1984). However, it is distinguished from it by the inclusion of a distinctive palmate morphotype of ?Dendrophyra sp., whose morphology may represent an adaptation to gliding over soft substrates.

The macrofossil assemblage includes ?vestimentiferan worm tubes, the bivalve molluscs vesicomyid sp. A, lucinid sp. A and Nuculana senni, and the gastropods Calliotropis sp., Abyssochrysos sp. and zygopleurid sp. B (Kugler et al., 1984; Gill et al., 2005). The assemblage is taxonomically similar to that of the living chemosynthetic community associated with 'cold' hydrocarbon seeps on the modern Barbados Accretionary Prism and elsewhere (Jollivet et al., 1990; Jones, 2006). Moreover, the containing carbonate sediments are characterized by a carbon isotope signature indicative of microbially-mediated oxidation of methane (Gill et al., 2005). The Joes River Formation is thus interpreted as having acted as a conduit for advecting methane.

\section{UPLIFT HISTORY}

Taking the palaeobathymetric interpretations discussed above as accurate, there appears to have been elevation or uplift throughout the deposition of the Oceanic Formation, Bissex Hill Formation, Conset Marl and Coral Rock Formation, as indicated on Figure 2.

The lower diagonal line on this figure represents the simplistic interpretation of the trend in elevation with respect to age within allowable ranges (indicated by shaded areas), and indicates uplift of $5000 \mathrm{~m}$ over $43 \mathrm{Ma}$, at a mean uplift rate of $120 \mathrm{~m}$ $\mathrm{Ma}^{-1}$. The mean uplift rate of $120 \mathrm{~m} \mathrm{Ma}^{-1}$ implied by this interpretation is inconsistent with - half - that of $220 \mathrm{~m} \mathrm{Ma}^{-1}$ inferred for the Coral Rock Formation on the basis of observation (see above).

The upper diagonal line represents an alternative interpretation of the trend in elevation with respect to age based on extrapolation back through time of the mean uplift rate of $220 \mathrm{~m} \mathrm{Ma}^{-1}$ calculated for the Coral Rock Formation, and indicates uplift of $5000 \mathrm{~m}$ over a shorter period of $23 \mathrm{Ma}$ (i.e. since the beginning of the Miocene). The abyssal palaeobathymetry for the Bissex Hill Formation implied by this uplift rate interpretation is inconsistent with - significantly deeper than the middle bathyal palaeobathymetry inferred on the basis of observation (see above).

Another alternative interpretation and, indeed, the only one that would be entirely consistent with all of the existing observations, is that the uplift rate was not constant, but varied through time, perhaps in response to emplacement of the Oceanic nappe(s) (J. Frampton, pers. comm., 2009). The actual uplift rate could at times have significantly exceeded the mean value and, indeed, could have been sufficiently high as to have given rise to emergence and erosion.

\section{CONCLUSIONS}

The age of the Scotland Formation of Barbados, based on foraminiferal evidence, is demonstrated to be Paleocene to ?early Middle Eocene; that of the Oceanic Formation late Middle Eocene to early Early Miocene; and that of the Bissex Hill Formation and Conset Marl late Early to early Late Miocene. The age of the Coral Rock Formation, based on electron spin resonance and other evidence, is demonstrated to be MiddleLate Pleistocene. The Joes River Formation is only present in a melange, such that its stratigraphical relationship to the other units is unclear.

The environment of deposition of the Scotland Formation, based on foraminiferal and other palaeontological evidence, is interpreted to be abyssal; that of the Oceanic Formation abyssal to lower bathyal; and that of the Bissex Hill Formation and Conset Marl middle to lower bathyal; and that of the Coral Rock Formation inner neritic. The Joes River Formation is interpreted as having formed by diapiric extrusion onto the seafloor and as having acted as a conduit for advecting methane.

Observed elevation/age relationships imply a mean uplift rate of between $120 \mathrm{~m} \mathrm{Ma}^{-1}$ and $220 \mathrm{~m} \mathrm{Ma}^{-1}$.

\section{ACKNOWLEDGEMENTS}

The author thanks Richard Dixon, then of BP Trinidad \& Tobago, for an invitation to attend a BPTT field trip to Barbados in 2005, Eric Deville of IFP, John Frampton of BioStrat, and Jim Pindell of Tectonic Analysis Ltd for discussions in the field, and Chris Moseley of Barbados National Oilfield Services Ltd for discussions regarding Woodbourne Field. Thanks also to John Frampton and an anonymous reviewer for constructive criticism of the original manuscript, and John Gregory for editorial assistance.

\section{Manuscript received 6 November 2007 Manuscript accepted 10 February 2009}

\section{REFERENCES}

Beck, C., Ogawa, Y. \& Dolan, J. 1990. Eocene Paleogeography of the Southeastern Caribbean: Relations between Sedimentation on the Atlantic Abyssal Plain at Site 672 and Evolution of the South America Margin. Proceedings of the Ocean Drilling Program, Scientific Results, 110: $7-15$.

Beckmann, J.P. 1953. Die Foraminiferenfauna der Oceanic Formation (Eocaen-Oligocaen) von Barbados, Kl. Antillen. Eclogae Geologicae Helvetiae, 46(2): 301-412.

Biju-Duval, B., Cauvet, J.P., Dufaure, P., Mascle, A., Muller, C., Richert, J.P. \& Valery, P. 1985. The Terrigenous and Pelagic Series of Barbados Island: Paleocene to Middle Eocene Slope Deposits Accreted to the Lesser Antilles Margin. In: Mascle, A. (Ed.), Geodynamique des Caraibes. Editions Technip, Paris, 187-197.

Bolli, H.M., Beckmann, J.P. \& Saunders, J.B. 1994. Benthic Foraminiferal Biostratigraphy of the South Caribbean Region. Cambridge University Press, Cambridge, 1032pp.

Caudri, C.M.B. 1972. The Larger Foraminifera of the Scotland District of Barbados. Eclogae Geologicae Helvetiae, 65(1): 221-234.

Caudri, C.M.B. 1996. The Larger Foraminifera of Trinidad (West Indies). Eclogae Geologicae Helvetiae, 89(3): 1137-1309.

Chaderton, N.A.N. \& Wood, L. 2007. Morphologic Architecture of a Coarse-Grained Turbidite: an Outcrop Study of the Scotland Formation, Barbados. In: Abstracts, American Association of Petroleum Geologists Annual Meeting, Long Beach, California.

Charnock, M.A. \& Jones, R.W. 1990. Aggutinated Foraminifera from the Palaeogene of the North Sea. In: Hemleben, C. et al. (Eds), 
Paleoecology, Biostratigraphy, Paleoceanography and Taxonomy of Agglutinated Foraminifera. Kluwer Academic, Dordrecht, 139-245.

De Cizancourt, M. 1948. Nummulites de l'Ile de Barbade. Memoires de la Société Géologique de France, 57: 6-37.

Dolan, J.F., Beck, C., Ogawa, Y. \& Klaus, A. 1990. Eocene-Oligocene Sedimentation in the Tiburon Rise/ODP Leg 110 Area: an Example of Significant Upslope Flow of Distal Turbidity Currents. Proceedings of the Ocean Drilling Program, Scientific Results, 110: 47-83.

Dolan, P., Burggraf, D., Soofi, K., Fitzsimmons, R., Aydemir, E., Senneseth, O. \& Strickland, L. 2004. Challenges to Exploration in Frontier Basins - The Barbados Accretionary Prism. In: Abstracts, American Association of Petroleum Geologists International Conference, Cancun.

Driscoll, N.W. \& Diebold, J.B. 1999. Tectonic and Stratigraphic Development of the Eastern Caribbean: New Constraints from Multichannel Seismic Data. In: Mann, P. (Ed.), Caribbean Basins. Sedimentary Basins of the World Series. Elsevier, Amsterdam, 591-626.

Fairbanks, R.G. \& Matthews, R.K. 1978. The Marine Oxygen Isotope Record in Pleistocene Coral, Barbados, West Indies. Quaternary Research, 10: 181-196.

Gill, F.L., Harding, I.C., Little, C.T.S. \& Todd, J.A. 2005. Palaeogene and Neogene Cold Seep Communities in Barbados, Trinidad and Venezuela: an Overview. Palaeogeography, Palaeoclimatology, Palaeoecology, 227: 191-209.

Gortner, C.W. \& Larue, D.K. 1986. Hemipelagic Rocks at Bissex Hill, Barbados: Sedimentology, Geochemistry and Depositional Environment. Journal of Sedimentary Petrology, 56(2): 307-316.

Gradstein, F., Ogg, J. \& Smith, A. 2005. A Geologic Time Scale 2004. Cambridge University Press, Cambridge, 589pp.

Harding, I.C. 1996. Rediscovery of the Type Lithology of the Siliceous Dinoflagellate Genus Peridinites Lefevre in Eocene Sediments of Barbados. Caribbean Journal of Science, 32(1): 64-71.

Hill, R.J. \& Schenk, C. 2004. Geochemistry of Barbados Oils, Gases and Petroleum Seeps: Implications for Barbados Petroleum Systems. In: Abstracts, American Association of Petroleum Geologists International Conference, Cancun.

Humphrey, J.D. \& Kimbell, T.N. 1990. Sedimentology and Sequence Stratigraphy of Upper Pleistocene Carbonates of Southeastern Barbados, West Indies. American Association of Petroleum Geologists Bulletin, 74(11): 1671-1684.

Jollivet, D., Faugeres, J.C., Griboulard, R. et al. 1990. Composition and Spatial Organisation of a Cold Seep Community on the South Barbados Accretionary Prism: Tectonic, Geochemical and Sedimentary Context. Progress in Oceanography, 24: 25-45.

Jones, R.W. 1994. The Challenger Foraminifera. Oxford University Press, Oxford, 149pp.

Jones, R.W. 1996. Micropalaeontology in Petroleum Exploration. Oxford University Press, Oxford, 432pp.

Jones, R.W. 1998. Palaeoenvironmental Interpretation of the Late Miocene and Pliocene of Trinidad based on Micropalaeontological Data. In: Ali, W., Paul, A. \& Young On, V. (Eds), Transactions of the Third Geological Conference of the Geological Society of Trinidad and the Fourteenth Caribbean Geological Conference, Trinidad. The Geological Society of Trinidad and Tobago, San Fernando, Trinidad, 86-101.

Jones, R.W. 1999. Forties Field (North Sea) Revisited: a Demonstration of the Value of Historical Micropalaeontological Data. In: Jones, R.W. \& Simmons, M.D. (Eds), Biostratigraphy in Production and Development Geology. Geological Society, London, Special Publications, 152: 185-200.

Jones, R.W. 2006. Applied Paleontology. Cambridge University Press, Cambridge, 434pp.

Jones, R.W. \& Charnock, M.A. 1985. 'Morphogroups' of Agglutinating Foraminifera, their Life Positions and Feeding Habits and Applicability in (Paleo) Ecological Studies. Revue de Paleobiologie, 4(2): 311-320.

Jones, R.W., Jones, N.E., King, A.D. \& Shaw, D. 1999. Reservoir Biostratigraphy of the Pedernales Field, Venezuela. In: Jones, R.W. \& Simmons, M.D. (Eds), Biostratigraphy in Production and Development Geology. Geological Society, London, Special Publications, 152: 243258.
Jones, R.W., Pickering, K.T., BouDagher-Fadel, M. \& Matthews, S. 2005. Preliminary Observations on the Micropalaeontological Characterization of Submarine Fan/Channel Sub-Environments, Ainsa System, South-Central Pyrenees, Spain. In: Powell, A.J. \& Riding, J.B. (Eds), Recent Developments in Applied Biostratigraphy. Geological Society, London, 55-68.

Jukes-Browne, A.J. \& Harrison, J.B. 1891. The Geology of Barbados. Part I. The Coral-Rocks of Barbados and other West Indian Islands. Quarterly Journal of the Geological Society, 47: 197-250.

Jukes-Browne, A.J. \& Harrison, J.B. 1892. The Geology of Barbados. Part II. The Oceanic Deposits. Quarterly Journal of the Geological Society, 48: 170-226.

Kaminski, M.A. \& Gradstein, F.M. 2005. Atlas of Paleogene Cosmopolitan Deep-Water Agglutinated Foraminifera. The Grzybowski Foundation, Krakow, Geological Society, London, Special Publications, 10: $547 \mathrm{pp}$.

Kasper, D.C. \& Larue, D.K. 1986. Paleogeographic and Tectonic Implications of Quartzose Sandstones of Barbados. Tectonics, 5(6): $837-854$.

Kugler, H.G., Jung, P. \& Saunders, J.B. 1984. The Joes River Formation of Barbados and its Fauna. Eclogae Geologicae Helvetiae, 77(3): 675-705.

Larue, D.K. 1985. Quartzose Turbidites of the Accretionary Complex of Barbados, II: Variations in Bedding Styles, Facies and Sequences. Sedimentary Geology, 42: 217-253.

Larue, D.K. \& Speed, R.C. 1983. Quartzose Turbidites of the Accretionary Complex of Barbados, I: Chalky Mount Succession. Journal of Sedimentary Petrology, 53(4): 1337-1352.

Machel, H.G. 2004. Geology of Barbados: A Brief Account of the Island's Origin and its Major Geological Features. Barbados Museum \& Historical Society, St Michael, 43pp.

Mahabir, K., Khandaker, N.I., Schleifer, S., Flores, D., Maksimonicz, H. \& Bang, D. 2004. Geochemical Analysis of Sandstones, Upper Scotland Formation (Eocene), NE Barbados: Clues to Provenance. In: Abstracts, Geological Society of America Annual Meeting, Denver.

Maurrasse, F. 1983. Radiolarian Stratigraphy, Paleoecology and Structure of the Oceanic Formation at Gay's Cove and Bath Cliff, Barbados. In: Abstracts, Tenth Caribbean Geological Conference, 372.

Mesolella, K.J. 1967. Zonation of Uplifted Pleistocene Coral Reefs of Barbados, West Indies. Science, 156: 638-640.

Pudsey, C.J. 1985. Stratigraphy and Sedimentology of the Scotland Group, Barbados. In: Transactions, Fourth Latin American Geological Congress, 1979, Trinidad \& Tobago, 903-908.

Pudsey, C.J. \& Reading, H.G. 1982. Sedimentology and Structure of the Scotland Group, Barbados. In: Leggett, J.K. (Ed.), Trench-Forearc Geology: Sedimentation and Tectonics in Modern and Ancient Active Plate Margins. Geological Society, London, Special Publications, 10: 291-308.

Saunders, J.B. 1968. Field Trip Guide: Barbados. In: Transactions, Fourth Caribbean Geological Conference, 1965, Trinidad, 443-449.

Saunders, J.B. \& Cordey, W.G. 1968. The Biostratigraphy of the Oceanic Formation in the Bath Cliff Section, Barbados. In: Transactions, Fourth Caribbean Geological Conference, 1965, Trinidad, 179181.

Saunders, J.B., Bernoulli, D., Muller-Merz, E. et al. 1984. Stratigraphy of the late Middle Eocene to Early Oligocene in the Bath Cliff Section, Barbados, West Indies. Micropaleontology, 30(4): 390-425.

Schellmann, G. \& Radtke, U. 2004. A Revised Morpho- and Chronostratigraphy of the Late and Middle Pleistocene Coral Reef Terraces on Southern Barbados (West Indies). Earth-Science Reviews, 64: 157-187.

Shackleton, N.J. \& Matthews, R.K. 1977. Oxygen Isotope Stratigraphy of Late Pleistocene Coral Terraces in Barbados. Nature, 268: 618-620.

Speed, R.C. 1981. Geology of Barbados: Implications for an Accretionary Origin. In: Proceedings of the 26th International Geological Congress, Paris, 259-265.

Speed, R.C. 1985. New Views on the Geology of Barbados. In: Transactions, Fourth Latin American Geological Congress, 1979 Trinidad \& Tobago, 929-941. 
Speed, R.C. 1988. Geologic History of Barbados: a Preliminary Synthesis. Transactions, Eleventh Caribbean Geological Congress, Barbados, 29: 1-11.

Speed, R.C. \& Larue, D.K. 1982. Barbados: Architecture and Implications for Accretion. Journal of Geophysical Research, 87(B5): 36333643.

Speed, R.C., Barker, L.H. \& Payne, P.L.B. 1991. Geologic and Hydrocarbon Evaluation of Barbados. Journal of Petroleum Geology, 14 323-342.

Steineck, P.L. \& Murtha, G. 1985. Foraminiferal Paleobathymetry of Miocene Rocks, Barbados, Lesser Antilles. In: Transactions, Fourth Latin American Geological Congress, Trinidad \& Tobago, 1979: $942-$ 951.

Steineck, P.L., Breen, M., Nevins, N. \& O'Hara, P. 1984. Middle Eocene and Oligocene Deep-Sea Ostracoda from the Oceanic Formation, Barbados. Journal of Paleontology, 58(1): 1463-1496.
Torrini, R. 1988. Structure and Kinematics of the Oceanic Nappes of Barbados. Transactions, Eleventh Caribbean Geological Congress, Barbados, 15: 1-15.

Torrini, R., Speed, R.C. \& Mattioli, G.S. 1985. Tectonic Relationships between Forearc-Basin Strata and the Accretionary Complex at Bath, Barbados. Geological Society of America Bulletin, 96: 861-874.

Van Morkhoven, F.P.C.M., Berggren, W.A. \& Edwards, W.A. 1986. Cenozoic Cosmopolitan Deep-Water Benthic Foraminifera. ElfAquitaine, Pau, (Bulletin des Centres de Recherches ExplorationProduction Elf-Aquitaine Memoire, No.11). 419pp.

Wood, K.C., Miller, K.G. \& Lohmann, G.P. 1985. Middle Eocene to Oligocene Benthic Foraminifera from the Oceanic Formation, Barbados. Micropaleontology, 31(2): 181-197. 